\title{
An improved method for the simple and accurate colorimetric determination of urea with Ehrlich's reagent
}

\author{
H. YATZIDIS, M. GARIDI, C. VASSILIKOS, D. MAYOPOULOU, \\ AND A. AKILAS \\ From the Second Department of Medicine, University of Athens \\ Medical School, Hippocratean Hospital
}

SYNOPSIS An improved method for the colorimetric determination of urea is described. The method is simple, requiring a deproteinized filtrate obtained after treatment of a small quantity of whole oxalated blood, serum, plasma or urine with $12.5 \%$ trichloracetic acid containing $50 \mathrm{~g}$. activated carbon. The addition of Ehrlich's reagent to this filtrate results in the immediate production of a stable yellow colour. The determination is accurate, very sensitive and rapid, taking place in only 10 minutes.

Levine, Leon, and Steigmann (1961) established a new method for the determination of urea, using Ehrlich's reagent, which, as already established (Ehrlich, 1901; Weltmann and Barrenscheen, 1922; Werner, 1939) reacts chromatometrically with urea, as well as with other substances such as urobilinogen, indican, phenol, allantoin, tryptophan, uric acid. According to the suggested method, urea is determined in blood and urine after the removal of the interfering substances by treating the deproteinized filtrate with activated carbon so that Ehrlich's reagent reacts with urea only. Levine et al. demonstrated the specificity of this reaction by the fact that this same filtrate, treated with urease, does not react colorimetrically with Ehrlich's reagent and by the evidence of identical spectral analyses of urea and blood filtrate complexes with Ehrlich's reagent. Levine et al. have in addition proved that the sulpha-derivatives which react with Ehrlich's reagent in a yellow-green colour are completely absorbed in charcoal. Acetone, up to $500 \mathrm{mg}$. per $100 \mathrm{ml}$. (higher values are usually found in the blood in diabetic acidosis), does not produce any significant colour with Ehrlich's reagent as modified by the authors, nor does ammonia interfere.

\section{METHOD}

1 DEPROTEINIZING REAGENT Activated carbon, $50 \mathrm{~g}$., is suspended in 1 litre of a $12.5 \%$ trichloracetic acid solution.

Received for publication 15 June 1963.
This reagent is kept in the refrigerator and can be used for a period of at least one week.

2 EHRLICH'S REAGENT (MODIFIED BY LEVINE ET AL., 1961) p-Dimethylaminobenzaldehyde, $5 \mathrm{~g}$., is dissolved in $20 \mathrm{ml}$. of concentrated hydrochloric acid. Distilled water is added to make up to $100 \mathrm{ml}$. This reagent is stored in a polyethylene bottle and can be kept in a refrigerator for many weeks.

PROCEDURE Eight $\mathrm{ml}$. of reagent 1 is added in a test tube to $2 \mathrm{ml}$. of whole oxalated blood or to $2 \mathrm{ml}$. of urine diluted 1 in 10 with isotonic saline solution and the contents are vigorously mixed two or three times during the next five minutes. The mixture is filtered through Whatman No. 50 paper. Then $1.0 \mathrm{ml}$. of reagent 2 is added to $4 \mathrm{ml}$. of the filtrate. The colour produced can be measured immediately, for it immediately reaches the maximum intensity and remains so for about two hours. The measurement is done in a spectrophotometer at $420 \mathrm{~m} \mu$ against the blank set at zero optical density. The blank is prepared in the same way as the sample, except that the blood or diluted urine is replaced with isotonic saline solution.

With the aid of a graph prepared by using known solutions of urea instead of blood and in the same quantity $(2 \mathrm{ml}$.) following the described procedure, the urea is directly determined in milligrams per $100 \mathrm{ml}$. (Fig. 1). When the urea concentration in blood is higher than $400 \mathrm{mg}$. per $100 \mathrm{ml}$. and Beer's law is not applicable, the determination is repeated with a sample diluted 1 in 2 with isotonic saline solution. In the case of diluted blood $(1: 2)$ or of diluted urine $(1: 10)$, the result obtained is multiplied by 2 and 10 respectively. 


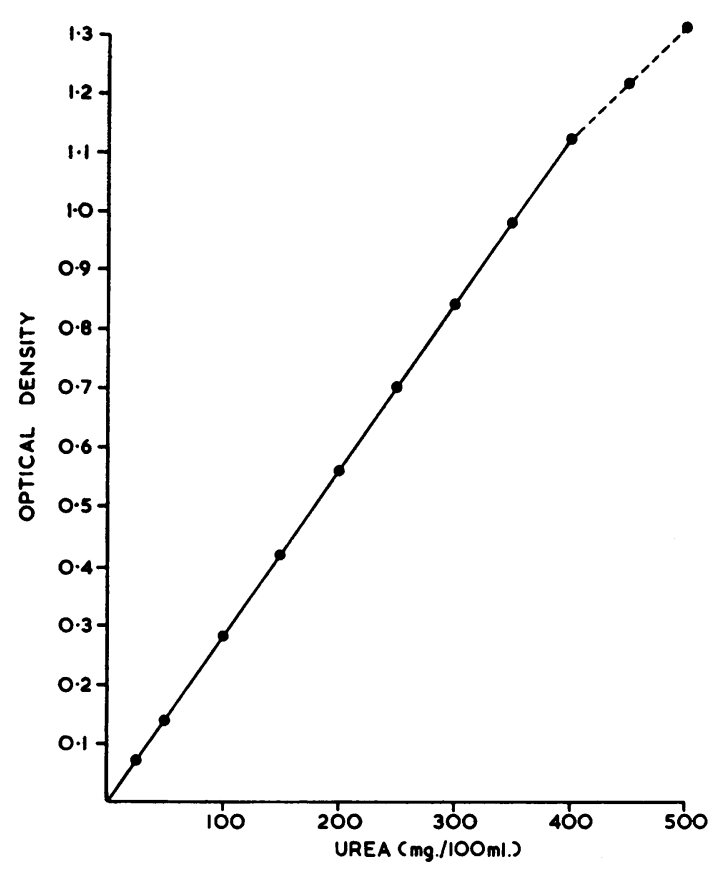

FIG. 1. Graph prepared with the use of known solutions of urea treated following the reported procedure. The colorimetric reaction measured in a Unicam 600 spectrophotometer at $420 \mathrm{~m}_{\mu}$ with a cuvette of $1 \mathrm{~cm}$. diameter follows Beer's law closely up to the concentration of $400 \mathrm{mg}$. per $100 \mathrm{ml}$.

\section{RESULTS AND DISCUSSION}

The present method represents the simplest of the hitherto known ones. Only a small quantity of the sample to be examined is required and the reagents needed are easily prepared and can be kept for a long time. The procedure then only consists in the deproteinization of the sample and the addition of Ehrlich's reagent. The entire procedure does not require more than 10 minutes.

The accuracy of this method has been tested by comparing the results obtained using this technique and the manometric determination of urea using Van Slyke's (1929) method.

\begin{tabular}{cc}
$\begin{array}{l}\text { Colorimetric Method } \\
\text { (mg./100 } \text { ml. })\end{array}$ & $\begin{array}{l}\text { Manometric Method } \\
(\text { mg./100 ml. })\end{array}$ \\
\hline 34 & 30 \\
35 & 38 \\
36 & 32 \\
40 & 38 \\
40 & 43 \\
44 & 41 \\
46 & 42 \\
53 & 56 \\
66 & 66 \\
66 & 74 \\
200 & 162 \\
255 & 245 \\
347 & 336 \\
364 & 348 \\
372 & 366 \\
400 & 391 \\
428 & 416 \\
445 & 434 \\
558 & 578 \\
585 & 605 \\
\end{tabular}

From these results it is evident that there is? excellent agreement between the two methods as $\vec{c}$ far as urea concentrations of 30 to $600 \mathrm{mg}$. peros $100 \mathrm{ml}$. are concerned.

Repeated determinations have proved that theo present method may be applied to measurements in serum or plasma as well as in whole blood. Theo results are not affected by oxalate or heparin.\% Moreover the method is very sensitive. Its practicalo sensitivity, according to the procedure described $\overrightarrow{\overrightarrow{0}}$ above, is 1 to $2 \mathrm{mg}$. up to concentrations of $100 \mathrm{mg}$. per $100 \mathrm{ml}$. The maximum error found among the replicates of a considerable number of normal and pathological blood samples was approximately $\pm 1.5 \%$. In 25 presumably healthy individualso ranging from 20 to 40 years of age, the range of 3 . urea values in whole oxalated blood was found too be 18 to $44 \mathrm{mg}$. per $100 \mathrm{ml}$.

\section{REFERENCES}

Ehrlich, P. (1901). Med. Woche, 2, 115.

Levine, J. M., Leon, R., and Steigmann, F. (1961). Clin. Chem., 7, 488 N Van Slyke, D. D. (1929). J. biol. Chem., 83, 449.

Weltmann, O., and Barrenscheen, H. K. (1922). Klin. Wschr., 1, 1100 , Werner, A. E. A. (1939) Lancet, 1, 18. 